Pete Alcock*

\title{
From Partnership to the Big Society: The Third Sector Policy Regime in the UK
}

DOI 10.1515/npf-2015-0022

Abstract: This article provides an overview of the changing balance of state and third sector relations in the UK over the last decade or so. It briefly sets this in the broader context of the changing nature of these relations over a longer historical perspective, and it develops the notion of interdependence as a framework for understanding how these relations have become established in the country. Recent political discourses and policy publications are drawn on to explain the shifts in policy regime under the Labour and Coalition governments in the UK in the early twenty-first century, emphasising the differences and similarities in these. The conclusion situates these regimes in a broader context of state and third sector analysis and the contested conceptualisation of civil society. Since 1999 third sector policy in the UK has been devolved to the separate administrations in Scotland, Wales and Northern Ireland; and this article focuses largely on developments in England only.

Keywords: third sector, state, United Kingdom, interdependence, third way, big society

\section{The UK Third Sector}

The focus of this article is on recent developments in the relationship between the state and the third sector in the UK; and in particular how this has changed over the last decade or so under the Labour governments of the 2000s and following the impact of the economic recession and the change of government in 2010. It draws on analysis of key policy initiatives and published documents from the Labour and Coalition governments to explore the major changes in state and third sector relations introduced by these two, apparently contrasting, administrations; and it develops the notion of interdependence to explain the underlying paradigm informing these policy regimes. The key political and policy events underpinning these changes are outlined in Box 1.

Corresponding author: Pete Alcock, School of Social Policy, University of Birmingham, Park House 40 Edgbaston Park Road, Birmingham B15 2RT, UK, E-mail: p.c.alcock@bham.ac.uk 
Box 1-Timeline of Key Policy Changes

1996-Publication of Deakin Commission on the Future of the Voluntary Sector

1997-Election of Labour government

1998-Establishment of Compact to govern state and third sector relations

1999-Devolution of political power and policy making (including third sector) to separate administrations in Scotland, Wales and Northern Ireland

2002-HM Treasury cross-cutting review recommends significant investment in third sector 2006-Creation of Office of the Third Sector (OTS) within Cabinet Office

2008/2009-Recession Summit meetings

2010-Election of Conservative-led Coalition government, Big Society launched, OTS becomes

Office for Civil society

2011-Elections in devolved administrations leads to different political control in these, no Big

Society discourse there

2012-Big Society discourse down-played

2015-Election of Conservative government, still led by David Cameron

Any assessment of recent developments in third sector policy has also to recognise that in practice there is contestation over key terms and definitions, and that these have some consequences for both the aims and the impacts of policy interventions. Although it has become widely recognised as the umbrella term for the sector, reference to the third sector has only relatively recently become common currency within the UK, associated in particular with Labour who wanted to extend its reach to a wide range of different forms of nongovernment organisations - according to their website at the time: "The term encompasses voluntary and community organisations, charities, social enterprises, cooperatives and mutuals both large and small". This broader conception was continued by the Coalition, although they did not like the term 'third sector'.

For the most part it is this wider sector that has been the site for policy planning therefore; and for terminological consistency it will be referred to here as the third sector - although in North America this is more generally known as the non-profit sector, in parts of Europe as the social economy, and in much of the rest of the world as the non-government sector. What this means, of course, is that this is a sector characterised by diversity and difference, perhaps as much as by any unifying characteristics; and this diversity must inform analysis of policy intentions, and policy outcomes.

The main infrastructure agency for third sector organisations in England, the National Council for Voluntary Organisations (NCVO), produce an annual Almanac containing key statistics about the sector in the UK (Kane et al. 2014). This suggests is that there were around 900,000 such organisations in the UK in 2012, although this included a broad estimate of 600,000 small grass-roots 
organisations which were not captured in any formal register. The main group of identified organisations was general charities, of which there were 161,300. Other organisations included in the almanac were cooperatives $(5,900)$, housing associations $(1,800)$ and sports clubs $(135,000)$. There has been a significant growth in the number of social enterprises within the sector in recent years, and, although there is no formal definition or measure of these (see Teasdale 2012), the numbers of companies limited by guarantee and community interest companies, which cover many, have been rising (Kane et al. 2014, 9).

Formal third sector organisations hold substantial assets of around £289 billion overall, with general charities holding £105 billion (Kane et al. 2014, 6). The annual income for charities in 2012 was around £39.2 million; but it is important to remember that most are very small, with over a half $(82,000)$ having an annual income of less than $£ 10,000$, and less than 5,000 more than $£ 1$ million (Kane et al. 2014, 15).The numbers of people employed in third sector organisations has also been growing, with around 800,000 working in general charities and the sector workforce constituting around $8 \%$ of the national total (Kane et al. 2014, 7). Estimates of voluntary activity based on national surveys suggest that around 12.7 million people in England, 29\% of the population, engage in formal volunteering at least once a month (Kane et al. 2014, 79).

Some of the data on the third sector in the UK is complicated by the fact that the broader definition of civil society organisations employed by the NCVO is not reflected in the main statistical data sources employed for much of the analysis in the Almanac. In particular the register of recognised charities maintained by the Charity Commission only covered those organisations which had registered with the Commission and met the statutory requirements for charitable status, and it applied only to England and Wales, with separate registration and records only recently introduced into Scotland and Northern Ireland.

The history of policy engagement with the third sector can be traced back over three centuries in the UK, at least to the middle of the nineteenth century (Finlayson 1994; Lewis 1995; Davis Smith et al. 1995; Harris 2010). In a review of these changes Lewis (1999) identified three broad shifts the relationships which flowed from them, ending with the move to partnership relations under the Labour government elected in 1997 (Lewis 2005). In general these changes produced ever closer engagement between the state and the sector; and this was supported on both sides. Two of the most important recent catalysts for change were the Wolfenden Committee of 1978 and the Deakin Commission of 1996. Both were established independently of government by the major infrastructure body for the sector in England, the NCVO, and yet both were taken up more or less directly by policy makers keen to improve their engagement with (what was then usually called) the voluntary sector (see 6 and Leat 1997). 
However, it is important to note that since the turn of the century third sector policy, along with many other aspects of social policy, has been devolved within the UK to the separate parliaments and assemblies in Scotland, Wales and Northern Ireland. This has meant that there is really no longer any UK policy regime for the third sector. There had been separate national umbrella agencies for the sector in the Scottish Council for Voluntary Organisations (SCVO), the Wales Council for Voluntary Action (WCVA) and the Northern Ireland Council for Voluntary Action (NICVA), plus a range of other national agencies operating in specialist areas such as social enterprise or organisational leadership, prior to devolution; but the transfer of powers and the creation of separate offices for the third sector (or equivalent) in each of the new administrations created the potential for 'new policy spaces' (Alcock 2012) to emerge in each separate regime.

Initially at least this did not lead to significant changes in policy direction, as the close engagement with the sector was followed by Labour-led administrations in each (Alcock 2012). Since the changes in political power in 2010 and 2011 (see Box 1), however, the devolved administrations have been less inclined to follow the lead taken for England by the Westminster government, and greater diversity in policy regimes has begun to develop. There is not the space here to explore this developing complexity and for the most part this article focuses on policy change in England since the late 1990s, which in any event comprises around $85 \%$ of the UK population.

\section{Independence or Support}

The core recommendation of the Deakin Commission in 1996 was that there should be closer, and better managed, relations between the third sector and the state. As explained below, this was largely taken up by the Labour government after 1997, building on some of the support for the sector developed by earlier governments following the Wolfenden Report, and leading to the creation of the new phase of partnership described by Lewis (2005). Central to this was a major expansion of state support for the sector, especially what Kendall (2003) referred to as horizontal support, available (in principle at least) to all sector organisations. This was largely welcomed by the leading agencies representing the sector, such as the NCVO, and it contributed, as we shall see, to the creation of a 'strategic unity' within the sector, based on the need to engage collectively with government (Alcock 2010).

However, the closer partnership with government promoted by the new Labour policy regime was criticised by some academics and sector representatives 
as threatening the independence of the sector. Academics like Carmel and Harlock (2008) argued that in effect government was using its support for the sector to establish this as a 'governable terrain'. And practitioners argued that incorporation into government policy agendas was leading to: isomorphism and hybridity, as organisations took on the form of other public service agencies; and mission drift, as a voluntary and user ethos was challenged by accountability to state contracting agencies (Billis 2010; Rochester 2013). Partnership with the state brought new and extensive horizontal investment into the sector, and a seat (or seats) at the tables of policy making; but, the critics argued, these came at a price, and that price was the independence of the sector (Smerdon 2009; NCIA 2011).

Ironically perhaps these concerns for sector independence were themselves challenged by the policy shifts which followed the election of the Conservativeled Coalition government of 2010-15, who withdrew much of the horizontal support which had been provided under Labour, including that provided to the leading infrastructure agencies. To a large extent the seats were removed from the decision-making tables by the new government; and the strategic unity that had brought the sector agencies to these tables was significantly weakened. As explained below, however, the change in policy direction under the Coalition was not so momentous; and in practice many of the underlying trends and policy initiatives that had been developing since the later 1990s were continued, even if with less direct financial support and obvious political enthusiasm.

This was because, whatever the up-front political rhetoric, state support for the third sector in the UK was well-established within government by the beginning of the new century, and largely welcomed and embraced by sector bodies. By 2000 the alleged independence of the third sector had already been compromised by its relations with the state. This had also been widely discussed in different forms by a number of commentators both within the UK and internationally. For instance, Billis (1989) had written about the overlapping boundaries between the sector and the state (and the market); and Dekker (2010) had argued that hybridity was a common feature of organisational forms across a range of countries where public policy engaged with the sector. Evers and Laville (2004) had explained this engagement between the state and the sector as the creation of 'tension fields', where relations between the two were played out.

What this broader analysis of these relations reveals is that these tension fields are in fact evidence not of the dependence or independence of the third sector, but of the interdependence of both sectors on each other. As we shall argue below, it is how this interdependence has been managed and developed over the last decade or so that is central to understanding the real impact of the changes in the policy regime in the UK - and this is true of many other welfare regimes too. 


\section{Partnership}

The Labour government which came to power in 1997 was quick to respond to the call for closer relations with the third sector included in the Deakin Commission Report of 1996, and when the party published its own review of relations with the sector, led by Alun Michael, a year later, much of what Deakin had proposed was endorsed in this (Labour Party 1997). This was early documentary evidence of the interdependence of policy makers - Deakin, though a strong advocate for the sector, was also a keen Labour supporter, and had advised Michael on the Labour review.

Much has been written about the broad thrust of wider political and policy agenda of 'New Labour' and the extent to which it was distinctive and innovative (see Driver and Martell 2006; Chadwick and Hefferman 2003). Central to the new policy environment however, at least in the early years, was the notion of a third way for public policy planning (Blair 1998; Giddens 1998), intended to capture a rejection of public service policy planning which relied primarily either on the state or the market. It also drew on the New Public Management reforms which were becoming dominant in policy practice (Pollitt 1990; and see Flynn 2012), and the pragmatic focus on 'what matters is what works' (Blair 1998 , 4) rather than who the providers of services are. There was much rhetoric in this third way discourse, and critics pointed out there was nothing new in promoting reliance on a mix of state and market forces or in being concerned to ensure that service delivery was effective. But in the context of third sector policy development it created the potential for a more proactive role for the sector to operate as a third force alongside the state and the market.

A government seeking to celebrate and promote a new welfare mixing was therefore likely to embrace voluntary and community activity, and to seek to bring it into the mainstream of political debate and policy planning (Macmillan and Townsend 2006). This is just what Labour did, leading to what Kendall (2009) described as the 'hyperactive mainstreaming' of state and third sector relations. For instance as the Prime Minister, Tony Blair, said in a speech to the 1999 NCVO Annual Conference:

History shows that the most successful societies are those that harness the energies of voluntary action, giving due recognition to the third sector of voluntary and community organisations. (Blair 1999)

This new engagement with the sector was also welcomed by key practitioners within it, who embraced the commitment to the creation of a partnership between the state and the sector which soon became the leitmotif of new 
Labour policy (Lewis 2005). For instance, Stuart Etherington, Chief Executive of NCVO opened a speech in 2002 with the words:

This is an exciting and challenging time for people working in the voluntary sector ... we have seen a growing understanding of, and emphasis on working with, the voluntary sector across government. Partnership working has become the norm ... (Etherington 2002).

There were a number of different dimensions to the Labour government's partnership with the third sector. Perhaps the most important symbolically was the creation of new institutions to provide focal points for the closer engagement that was planned. One of the key recommendations of the Deakin Report (1996) had been the need for some formalisation of relations through a governing 'concordat'. This was taken up quickly and in 1998 the government established a national Compact in England to provide a framework for relations between central government and third sector organisations (Home Office 1998). Similar Compacts, with much the same aims and structure were implemented shortly after in Scotland, Wales and Northern Ireland. The national Compact was also promoted as a model for local compacts, and over the next few years local compacts were implemented in virtually all areas by local authorities, National Health Service agencies and other public bodies (Craig et al. 2002). The Compact was a framework for relations, not a legally binding document; and it required both parties to undertake proactive engagement with its guidance and procedures to make it work. National guidance was thus issued on a number of key mattes of concern and later an independent agency, the Compact Commission, was established by government to oversee its implementation and promote good practice under it.

The Compacts provided documentary actualisation of the mainstreaming of state and third sector relations - codifying in official statements what had often been good practice in state and third sector relations. They also became something of a model for similar attempts to regularise the interdependence of the sector and the state in other developed welfare regimes (see Casey et al. 2010).

The Labour government also moved quickly to reform its internal structures for engagement with the sector. It rebranded the Home Office Voluntary Service Unit the Active Community Unit (ACU) and extended its three year budget by $£ 300$ million. A new Charity and Third Sector Finance Unit was created in the Treasury to co-ordinate fiscal policy for the sector; and a Social Enterprise Unit (SEU) was set up in the then Department of Trade and Industry (DTI) to provide co-ordination and support for social enterprises. The most significant change came in 2006, however, when (with the exception of the Treasury unit) these were all merged into the Office for the Third Sector (OTS), based at the heart of government in the Cabinet Office. 
The OTS took over co-ordination of all government policies and investments for the sector, giving it a portfolio and a budget much larger than its separate constituents. It was supported by a new Minister for the Third Sector within the Cabinet team (the first incumbent was Ed Miliband, later leader of the Labour Party), and it had a director, Campbell Robb, who had previously worked at NCVO as its policy lead and who had a strong practice base within the sector. His appointment was significant, because senior civil service posts were usually filled by experienced government officers, and it was a clear indication that the partnership and interdependence between the government and the sector could lead to transfer of people as well as ideas and resources, and that a sector perspective and experience could be valued at the centre of government. Under Robb the OTS established formal mechanisms for engagement, creating an Advisory Body of senior sector representatives and a group of Strategic Partners - the leading third sector infrastructure bodies, who all received funding from the Office to support their partnership work. The OTS also worked to establish links across central government service departments, recruiting senior civil servants as 'third sector champions' in each department.

Another of the recommendations of the Deakin Commission had been that the law on the definition and regulation of charities should be reviewed and updated. The government also took this forward in the Charities Act of 2006, simplifying the definition of charities for the first time in over three centuries and linking it to the need to demonstrate 'public benefit'(Cabinet Office 2002). Like the Compact and the OTS, charity law reform applied to all third sector organisations; and together these symbolised what Kendall (2003) argued was a shift from vertical support for the sector (based within particular policy fields) to horizontal support (provided for any organisations and agencies across the sector).

This horizontal support included in particular financial investment in the sector by government, to help it to deliver on the partnership commitments which flowed from policy mainstreaming. Critical to this was a cross cutting review of the role of the sector in public service delivery, initiated by the Treasury as part of the government's wider plans for public spending, the Comprehensive Spending Review (HM Treasury 2002), and revisited in 2004 and 2005 (HM Treasury 2004, 2005). The review led directly to the development of significant new streams of investment to support third sector organisational development.

The first of these was the Futurebuilders fund, initially £125 million over three years from 2005 to 2008, to provide grants or loans to third sector organisations to help equip them to bid for public funding, and later expanded to $£ 215$ million and continued for 2008 to 2011. Delivery of the programme was transferred to a new independent agency, the Social Investment Business (SIB), which became a major source of investment support for the sector. It also 
administered the $£ 70$ million Communitybuilders fund, established by the Department for Communities and Local Government and the OTS in 2008 to provide support for small local and community based organisations, and the $£ 100$ million Social Enterprise Investment Fund, established by the Department of Health, to provide support for social enterprises bidding to deliver health and social care services. SIB funding was sometimes in the form of loans, which in principle at least would be repaid as the business of organisations expanded and developed.

In addition to the horizontal funding provided through SIB, the government introduced another programme in 2004 called ChangeUp to provide support for infrastructure agencies delivering capacity building services to third sector organisations. The ChangeUp programme provided significant additional resources of $£ 150$ million, directed at identified organisational needs such as workforce development and information technology; and, after 2006 it was delivered by a separate government agency called Capacitybuilders. This led some third sector pundits to refer to these horizontal investment initiatives as the 'builders' programmes; and certainly the theme of investing in building up the capacity of organisations ran through them all.

The focus of much of the horizontal investment outlined above was on supporting organisational and sector development, and in particular strengthening the capacity of organisations to be able to take on contracts for the delivery of public services, as part of the government's more general third way strategy. However, there were also other policy initiatives for partnership working with third sector organisations, informed by rather different political objectives.

When launching the Compact in 1998, the Prime Minister had praised third sector organisations because,

They enable individuals to contribute to the development of their communities. By so doing they promote citizenship, help to re-establish a sense of community and make a crucial contribution to our aim of a just and inclusive society (Home Office 1998).

Following this in 2003 the government published a strategy document on Building Civil Renewal (Home Office 2003) and established a separate Civil Renewal Unit to provide support for third sector partnership in community based regeneration activity. The unit was merged into the OTS in 2006, but support for this civil renewal activity continued and was part of a continuing policy discourse on the role of the third sector in the promotion of democratic engagement and the enhancement of social capital, which contrasted with the mixed economy and service delivery discourse which underpinned the earlier Treasury cross cutting review.

The civil renewal discourse was also likely to focus on smaller communitybased associations rather than the larger, more business-like, organisations 
involved in the delivery of public services; and one effect of this was to threaten a bifurcation in partnership relations with the sector, between the larger wellfunded delivery organisations, and the smaller less well-established community groups. That the former were more likely to share the aims of their public funders and the latter were more likely to be challenging or even campaigning against public agencies, made this division potentially more politically problematic too - for both government and third sector partners. What it reflected, of course, were the different aims and structures of organisations within the third sector, and the different forms that the interdependence between these organisations and the state took, with some smaller organisations perhaps more prepared to use their position and their funding to challenge state policies or practices (Milbourne 2013, Ch. 8).

This bifurcation was cast into the shadows in 2008 and 2009, however, when the economic recession began to threaten all sources of financial support for the sector. At this point all the leading third sector infrastructure bodies in England moved collectively to establish two 'recession summit' meetings to share their experiences and concerns, and to lobby government for additional horizontal support to respond to these. Around 25 sector leaders attended these summits, together with the Minister and officers from OTS. There were calls for significant new investment to meet the challenges of the recession; and the government responded by implementing a Third Sector Action Plan based on a £42.5 million package of investment - although this was much less than some in the sector had hoped for, and included some funding which was in practice already in place.

These summit meetings were, in the short term at least, an example of the success of the partnerships relations established under the Labour governments. The forums for dialogue had been established through the work of the OTS and the investments in the Strategic Partners. The leading sector agencies were confident that they could call on government in what they felt were times of need; and the government acted in response, increasing horizontal support for the sector to go some way to meeting the demands made. Despite the diversity of third sector organisations and the different discourses which had informed policy interventions, therefore, there was evidence here of a 'strategic unity' (Alcock 2010) across the sector in seeking to work in partnership with government to promote horizontal investment to protect and develop third sector organisations. What is more third sector organisations mostly welcomed the partnership agenda and participated actively in it, in particular the infrastructure agencies involved in delivering some of the horizontal funding and the large service delivery charities commissioned to deliver public services.

The recession summits, were the high water mark of the deepening interdependence of the state and the sector under Labour. Sector representatives felt 
confident in seeking support from government; and government felt obliged to respond in order to sustain the contribution made by voluntary action and organisation. However, at the height of the recession in 2010, there was a general election, and a new Coalition government was elected, who it soon became clear had a rather different view of government support for and engagement with the third sector.

\section{Big Society}

The Coalition government was led by the Conservative Party, and its leader David Cameron, who became Prime Minister. Whilst in opposition the Conservatives had published a 'green paper' outlining their thoughts on Voluntary Action in the 21 $1^{\text {st }}$ Century (Conservative Party 2008). In 2009 Cameron followed this in the 'Hugo Young Lecture', where he outlined his support for a 'Big Society' to replace big government, arguing that,

Because we believe that a strong society will solve our problems more effectively than big government has or ever will, we want the state to act as an instrument for helping to create a strong society ... Our alternative to big government is the big society. (Cameron 2009).

This notion of the Big Society became part of a new political discourse on the relations between government and the third sector. It was the focus of a Conservative election paper on Building a Big Society (Conservative Party 2010) and an early policy paper from the new Coalition government on Building the Big Society (Cabinet Office 2010). This policy paper was launched shortly after the 2010 election by Cameron himself in the garden of 10 Downing Street. He followed this later with a number of other speeches on the Big Society, notably in Liverpool in July 2010, when he launched the Community Vanguards initiative mentioned below, and when he described the idea as his 'great passion'.

The Big Society was a key part of the new political discourse being developed by the Conservatives under Cameron. It was a discourse intended to distance the Party, and later the government, from the supposed big state politics of the Labour Party and their support for comprehensive public services, and from the free market neo-liberalism which was at that time associated closely with the 2008 economic recession. In this respect it was similar to the Labour Party's earlier third way discourse; and indeed, despite the appeal of the rhetoric, it had much in common with Labour's commitments to a mixed economy of welfare providers and the interdependence of third sector organisations operating 'between' the state and the market, as we shall return to discuss below. 
The broader political discourse also attracted contributors outside of the government. The Conservative MP, Jesse Norman (2010), published a book on the subject, linking Big Society thinking back to the roots of Conservative politics in the later eighteenth and early nineteenth centuries. The independent think tank, Respublica, led by Phillip Blond also published books outlining the need to develop a new politics between the 'left and right' (Blond 2010). A new third sector organisation, the Big Society Network, was set up to promote new forms of community organising. New supporters were also brought into government, notably Nat Wei, a third sector activist, who was made a member of the House of Lords to act as an unpaid advisor on the Big Society.

The Big Society discourse promised to extend beyond Cameron and the Conservative Party, therefore, and to champion a new approach to non-government collective action. It also coincided, however, with the introduction of massive cuts in public expenditure announced in the 2010 Spending Review as part of the new government's commitment to reduce the public sector spending deficit that the country faced. This led political critics, such as the New Economics Foundation, to suggest that in practice the Big Society was little more than a fig-leaf to cover the yawning gaps that would soon be appearing in public services (Coote 2010). Although Cameron himself claimed that his support for the Big Society was not just because of the need for government cuts, but was about a new political rhetoric for smaller government, which a Conservative government ought to be promoting whatever the economic context.

Whatever the political rhetoric, however, and as we shall see this was inevitably somewhat short-lived, what mattered for the third sector in the country was what this political rhetoric might mean in policy terms - in particular, of course, because it was third sector organisations who might be expected to fill the spaces between the state and the market, which would be opened up by the retrenchment planned in public service provision. Here there were some significant developments, intended, at least in principle, to distance the new government from Labour's previous partnership agenda and perhaps to promote a new relationship between the state and the third sector in the country.

The most important symbolic change was the retitling of the OTS as the Office for Civil Society (OCS). Cameron in particular had said that he did not like the term third sector (and in any event it was closely associated with Labour); and so the government began to refer to the sector as civil society. Civil society is a rather different concept to third sector, with a longer history and a broader theoretical reach, as discussed later. But in practical terms the UK government still intended it to embrace the broader scope of third sector organisations mentioned above; and they still retained a central department, within the Cabinet Office, to manage relations with these. They also continued with a 
Minister for Civil Society, Nick Hurd, who remained in the post until 2014. At this broader structural level therefore there was significant continuity of practice, despite the altered rhetoric.

However, much of the support for the third sector which had been provided by the OTS under Labour was rapidly scaled back. The investments in the 'builders' programmes were discontinued, and the associated agencies like Capacitybuilders and the Compact Commission were closed down. The Compact itself was retained, but was slimmed down and, without its associated supporting agency, was soon marginalised in most government departments. The OTS Advisory Body was dismissed and the financial support for the Strategic Partners was phased out. Overall these amounted to a cut back of around 60\% in the budget of the OCS, which itself was reduced in size. The Strategic Partners, the leading sector agencies, complained that this meant that they could no longer act to provide a strong sector voice to government; but to some extent this was just what the new government intended. The aim was to signify a clear policy break from the partnership and hyperactive mainstreaming of the Labour era, in particular through the abandonment of the commitment to extensive horizontal support for the third sector, and a return to a much more limited vertical engagement with government on specific policy initiatives or in the delivery of particular service contracts.

There were nevertheless some more specific policy initiatives developed and delivered by the OCS. A Red-tape Taskforce explored ways to remove barriers to local community action; and a Mutuals Taskforce sought to promote the floatingoff of public services to independent organisations set up by former public workers, under what was called the 'Right to Provide'. Funding of around £2 million was provided to kick-start the training of 5,000 local community organisers, based on a model supposedly imported from the US; and £50 million was provided for community first grants to co-fund local endowments. A new national programme was also introduced within the OCS, based on ideas promoted by advisors to the Prime Minister. This was the National Citizens Service, which aimed to provide short term volunteering opportunities for 16 year olds in their summer vacations. These were fully funded by government and delivered by selected volunteer providers; but inevitably could only reach a maximum of around 30,000 young people each year (out of an age cohort of around 750,000), and in practice did not even reach target numbers in the first few years.

These were small scale investments compared with the support provided through OTS under Labour, but they continued some commitment from government to support at least those activities which they wanted third sector organisations to participate in. The government had also said that they wanted to encourage investment in the sector more generally, and this became part of an attempt to encourage what they referred to as 'social investment'. At the centre 
of this was the belief that third sector organisations could benefit from investment loans linked to business development, and that some investors would be keen to make these loans if the vehicles to promote and co-ordinate such activity existed. What is more, in particular at times of cutbacks in public funding, the promotion of these forms of social investment was felt to be a more appropriate role for a government that nevertheless wanted to get more resources into the sector. In addition to the Social Investment Business (SIB), which the government continued to promote, they established a new social investment bank, Big Society Capital, with resources from the leading private banks, including the funds in some of their dormant bank accounts, and able to make loans on preferential terms to third sector organisations who wanted to grow their businesses.

The previous Labour government had already been planning to introduce a social investment bank along the lines of Big Society Capital; and in this area, as in a number of others, the Coalition government was in fact continuing policy interventions developed by Labour, despite the rhetorical attempts to distance themselves from these. The support for public sector workers to establish new mutual organisations to deliver their services independently of government in the Right to Provide, had also been promoted by Labour, who called it a Right to Request. And this was part of a much broader commitment by both governments to increase the role of third sector organisations in the delivery of public welfare services, as part of more general strategies to promote user choice through the availability of alternative service providers. This was promoted by the publication in 2011 of a White Paper entitled Open Public Services, followed by new guidance on commissioning for public agencies and the passing of the Public Services (Social Value) Act 2012, which was supposed to promote the use of social value assessments in the commissioning of services.

Before 2010 it had been social care provision, commissioned by local authorities, which had provided the main opportunities for third sector organisations to take over the provision of public services, although this also attracted many private sector providers, especially in the residential field. But after that some other significant public service programmes were contracted-out, most notably the Work Programme from the Department of Work and Pensions, which provided employment advice and work placements for the long term unemployed, and later probation service support for ex-offenders from the Ministry of Justice.

However, these central commissioning procedures also included a greater focus on the outcomes of services, in particular the linking of contract payments to the achievement of specified performance indicators. As a result of this, in the Work Programme in particular, it was private companies, rather than third 
sector organisations, who secured most of the major contracts, largely because only they had the financial capital and organisational scale to take on the risks of contracting, with voluntary providers mainly only involved as sub-contractors in some specialist fields. What is more, despite the existence of the 'Social Value Act', there was no significant move to define what this might mean, or to use it to promote the particular value of third sector providers to public service commissioners. In practice, therefore, it was market competition rather than voluntary and community action which increasingly began to dominate public service reform in the UK.

The other significant dimension of the Coalition's policy agenda with potential to impact on state and third sector relations was the promotion of what the government referred to as 'localism'. This was shorthand for the encouragement of locally based community action to provide 'bottom-up' solutions to local needs; and it included the Community Vanguards initiative, launched by Cameron in Liverpool in 2010. This was intended to provide support for local people to take control of their own local services, such as shops, pubs or broadband delivery, although it only covered four relatively small local areas: Liverpool, Windsor and Maidenhead, Sutton, and the Eden Valley in Cumbria. It was not a success, however. Liverpool withdrew shortly after the launch claiming that the cuts to local authority budgets there meant that supporting local action was no longer really feasible; and after about a year support for the other vanguards was quietly withdrawn. Despite the Big Society rhetoric of the promotion of 'bottom-up' community change, there was little evidence here of community support for new forms of voluntary action.

This was a relatively early example of the limitations that were beginning to be exposed by- the impact of the policy initiatives flowing from the Big Society rhetoric. Another early casualty was the abandoning of plans for a national 'Big Society Day' to provide an annual focus for voluntary action. What is more, most of the new policy initiatives had relatively little reach, especially within the third sector. Public service reform mainly favoured private providers. There was little appetite for social investment, from both investors and third sector organisations. And new programmes such as the National Citizens Service and the Community Organiser scheme, were very small scale - especially when compared to the horizontal investment developed under the previous government.

As mentioned above, the Big Society was in fact a political discourse rather than a policy programme; and, as with most political rhetoric, initial enthusiasm soon began to wane. In 2010 David Cameron had mentioned the term four times in his Party Conference speech. By 2013 it was not mentioned at all. The idea had never in practice commanded much support across the main service providing government departments, and the Ministers representing these did not really 
take it up. Supporters outside government also began to fall away. Nat Wei quit his role as government advisor in 2012, claiming that he could no longer afford to dedicate his time to such voluntary activity. Jesse Norman fell from favour after twice voting against the Government in the Commons. Respublica lost financial support and political influence. And the Big Society Network was investigated by the Charity Commission and the National Audit Office for misuse of public funds.

The response of the third sector to the changing policy regime of the Coalition government was also a rather mixed one. In principle the Big Society rhetoric has appeared to offer exciting new opportunities for sector organisations and community action to be at the centre of a reconstruction of the role of the state and the delivery of public services; but in practice the impact of policy change on the sector was much less positive. The failure of the Community Vanguards revealed that at grass-roots level there was little capacity, or will, to lead a significant shift in the scale and scope of local community action. The opening up of public services did not in general see a major increase in third sector activity here for, as mentioned, the legislation on social value did not in practice help organisations to win contracts in competition with large private sector providers, better able to manage and deliver the outcome focused contracts. More generally the withdrawal of a large proportion of the financial support for the sector that had previously been provided by the state, in particular at local government level, led to a decline in the sector's income from government of almost 9\% from 2011 to 2012 (Kane et al. 2014, 23), with further reductions inevitable in the following years.

Qualitative research from the UK Third Sector Research Centre also revealed scepticism about any potential benefits of the Big Society for individual organisations, coupled with a pragmatic concern to try and position themselves within this new discourse (Macmillan 2013). And further research on public attitudes suggests that overall these were negative, with a number of responses commenting that it would be unlikely to affect their commitments to voluntary action and expressing concerns about the ability of their local communities to take on significant new responsibilities (Lindsey and Bullock 2013). What is more, academic critics (Milbourne 2013; Rochester 2013) pointed to the divisive impact of the new policies for public service contracting and social investment, which they argued were only likely to be of benefit to large provider organisations with robust business planning. Conversely, they suggested, the (often smaller) campaigning and community-based organisations that criticised and challenged government may be seen as a potential threat to a government that did not view interdependence as an opportunity for third sector organisations to 'bite the hand that fed them'. 


\section{Policy Agendas and Political Discourses}

What this brief analysis of the third sector policy regime in the UK over the last decade has revealed has been the over-riding importance within this of the changing relationship with the state. As mentioned at the beginning, this changing relationship has a longer history, and to some extent is rooted in the critical role that the state has played in the development and delivery of social policy in the country over the course of last century - as is the case in other Western European nations. However, over the last decade or so these changes became more rapid, and rather more dramatic, with political and policy engagement reaching a high water mark under the hyperactive mainstreaming of the Labour governments, to be replaced by a more disengaged approach under the Conservative-led Coalition government, who were also committed to bringing about significant reductions in the economic and political role of the state.

These changes have been reflected in different political discourses - from the Third Way partnership approach under Labour to the Big Society rhetoric promoted, initially at least, by Cameron and the Conservatives. However, as we have suggested, this has not necessarily been carried through into policy change. A number of the key features of the policy environment have in fact remained fairly constant. These include commitments to increasing the role of third sector organisations in the delivery of public services, seeking to promote new forms of investment in the sector and promoting citizen action and community organisation, and the maintaining of a dedicated office at the centre of government to lead on these and other related policy initiatives.

All of these have continued the longstanding inter-relationships between the third sector and the state in the UK, with similar developments to those in England taking place in the new devolved administrations in Scotland, Wales and Northern Ireland. Although some critics have argued these have threatened the independence of the sector (Milbourne 2103; Rochester 2013) or led to the constitution of it as a 'governable terrain' by the state (Carmel and Harlock 2008), in practice it was interdependence which dominated relations under both regimes, albeit with different degrees of political rhetoric and policy reach.

The widespread horizontal support developed under Labour was cut back under the Coalition, at a time when expenditure cuts were extended across all government spending to tackle the deficit in the public sector finances. Yet, despite the rhetoric of the Big Society as a substitute for big government, the policy focus on the sector continued through the maintenance of the Office for Civil Society, and the support provided for schemes favoured by the government. What is more, many of the major foci for engagement between the sector and the 
state continued and were expanded under the Coalition, including the commissioning of third sector organisations to deliver public service contracts and the state support for social investment into the sector.

In practice, therefore, the question policy makers and practitioners have been addressing, has not been whether the state should intervene within an independent third sector, but rather what form such intervention and support should take. This question focuses rather on the interdependence of the state and the third sector, and it has posed particular challenges for the sector itself, not the least because the changing forms of support, and political engagement, have benefitted organisations within the sector differentially. This has had both positive and negative consequences for these different organisations; and it has meant that the 'strategic unity' (Alcock 2010) that some policy makers and sector leaders had wanted to create within the sector has always been a fractured and fragile one.

There are lessons for the understanding of state and third sector relations in other countries from the interdependence experienced in the UK over this period. Given the long history of these relations, rapid and significant change is always in practice unlikely; and, whatever governments may claim, there is often a gap between political rhetoric and policy reality. In practice interdependence is well-entrenched in the practices of both state policy makers and third sector practitioners; and this is a pattern which can be found in other advanced welfare regimes. Concerns about hybridity, isomorphism and independence are not exclusive to the UK. Indeed, as Dekker (2010) has argued, hybridity has become a common feature of the overlapping boundaries (or 'tension fields', Evers and Laville 2004) between the sectors.

These challenges can be found in other European countries, and in all, third sector organisations continue to prosper without becoming absorbed into either the state or the market. Indeed hybridity, autonomy, business planning, contracting and public regulation are important dimensions of third sector relations in many different national contexts, and are at the centre of the changing relations with the state that many organisations have to manage. What had been happening within the UK, in particular under the hyperactive mainstreaming of Labour, was an example of high profile policy engagement with, and government support for, the sector; but it was only one manifestation of trends that are common elsewhere.

Perhaps the most telling reflection on the established nature of state and third sector relations in the UK was the lack of political discussion and policy debate on the sector in the 2015 general election. Third sector issues had a low profile in the election, which was something of a contrast with 2010 (see Alcock et al. 2012). However, all the leading political parties were in practice committed to a continuation of the policies and practices of the Coalition and the OCS. 
Indeed all seemed by then to have accepted the civil society terminology of the Coalition, including the leading sector agency, the NCVO, whose annual collection of statistical data on the sector is now called The UK Civil Society Almanac.

However, despite the shift in terminology the politics and policies of the UK remain focused on the interdependence of state and third sector relations rather than the broader civil society discourses being developed by Edwards (2014) and in the Journal of Civil Society, or as outlined by Evers (2013) in his review of the different ways in which civil society discourse can embrace the values and the practices of social relations across all sectors of social provision. Interdependence, whilst recognising the mutual engagement and reliance of the third sector and the state, still tends to treat these as essentially different sectors of public life, with civil society sometimes being employed as a synonym for the third sector - as in the Office for Civil Society.

For Edwards (2014) in particular this is only one element of a broader set of discourses on civil society, which include the conception of civil society as the public sphere in which all forms of collective action take place, and of which the state, the third sector and even the market are only different - though not distinctive - dimensions. This also involves a normative discourse on how civil society can act as the site for the promotion, and realisation, of the 'good society' or the 'common good'.

Such a conception of civil society is beyond the aspirations of the policy regimes within the UK over the last two decades, or longer. As explained here, their focus has been on the changes in the balance of interdependency between the state and the third sector, which, despite their 'tension fields' continue to be identified as distinctive dimensions of public life. An office for civil society which wanted to go beyond this would need to rethink how all sectors operate within the public sphere, and act to promote the public good; but this is not part of the policy agenda in the UK at the present time.

Funding: The Charles Stewart Mott Foundation is a major sponsor of Nonprofit Policy Forum, underwriting its open access to the public. Other sponsors include the Levin College at Cleveland State University and the Association for Research on Nonprofit Organizations and Voluntary Action. This special issue was funded through a grant by the Kresge Foundation to ARNOVA.

\section{References}

6, P., and D. Leat. 1997. "Inventing the British Voluntary Sector by Committee: From Wolfenden to Deakin.” Non-Profit Studies 1 (2): 33-47. 
Alcock, P. 2010. "A Strategic Unity: Defining the Third Sector in the UK." Voluntary Sector Review 1 (1): 5-24.

Alcock, P. 2012 "New Policy Spaces: The Impact of Devolution on Third Sector Policy in the UK." Social Policy and Administration 46 (2): 219-38.

Alcock, P., J. Kendall, and J. Parry. 2012. "From the Third Sector to the Big Society: Consensus or Contention in the 2010 UK General Election." Voluntary Sector Review 3 (3): 347-64.

Billis, D. 1989. The Theory of the Voluntary Sector: Implications for Policy and Practice. London: London Centre for Voluntary Organisation, London School of Economics and Political Science.

Billis, D. 2010. "Towards a Theory of Hybrid Organisations." In Hybrid Organisations and the Third Sector: Challenges for Practice, Theory and Policy, edited by D. Billis. Basingstoke: Palgrave.

Blair, T. 1998. The Third Way: New Politics for the New Century. London: Fabian Society.

Blair, T. 1999. Speech to National Council for Voluntary Organisations Annual Conference, February 1999.

Blond, P. 2010. Red Tory: How the Left and Right Have Broken Britain and How We Can Fix It. London: Faber and Faber.

Cabinet Office. 2002. Private Action, Public Benefit: A Review of Charities and the Wider Not-for-Profit Sector. London: Cabinet Office.

Cabinet Office. 2010. Building the Big Society. Cabinet Office: London.

Cameron, D. 2009. 'The Big Society' Hugo Young Memorial Lecture, 10th November 2009.

Carmel, E., and J. Harlock. 2008. “Instituting the 'Third Sector' as a Governable Terrain:

Partnership, Procurement and Performance in the UK." Policy and Politics 36 (2): 155-71.

Casey, J., B. Dalton, R. Melville, and J. Onyx. 2010. "Strengthening Government-Nonprofit Relations: International Experiences with Compacts.” Voluntary Sector Review 1 (1): 59-76.

Chadwick A., and R. Hefferman, eds. 2003. The New Labour Reader. Cambridge: Polity Press.

Conservative Party. 2008. A Stronger Society: Voluntary Action in the 21st Century, Policy Green Paper No. 5. Conservative Society: London.

Conservative Party. 2010. Building a Big Society. London: Conservative Party.

Coote, A. 2010. Cutting It: The 'Big Society' and the New Austerity. London: New Economics Foundation.

Craig, G., M. Taylor, M. Wilkinson, and S. Monro. 2002. Contract or Trust? The Role of Compacts in Local Governance. Bristol: Policy Press.

Davis Smith J., C. Rochester, and R. Hedley, eds. 1995. An Introduction to the Voluntary Sector. Routledge: London.

Deakin Commission. 1996. Meeting the Challenge of Change: Voluntary Action into the $21^{\text {st }}$ Century, Report of the Commission on the Future of the Voluntary Sector in England. NCVO: London.

Dekker, P. 2010. "Civicness: From Civil Society to Civic Services.” In Civicness in the Governance and Delivery of Social Services, edited by T. Brandsen, P. Dekker, and A. Evers. Baden Baden: Nomos.

Driver, S., and L. Martell. 2006. New Labour, 2nd ed. Cambridge: Polity Press.

Edwards, M. 2014. Civil Society, 3rd ed. Cambridge: Polity Press.

Etherington, S. 2002. 'Delivery: The Role of the Voluntary Sector', Public Management and Policy Association Lecture, 22 October 2002. 
Evers, A. 2013. "The Concept of 'Civil Society': Different Understandings and Their Implications for Third Sector Policies.” Voluntary Sector Review 4 (2): 149-64.

Evers A., and J.-L. Laville, eds. 2004. The Third Sector in Europe. Cheltenham: Edward Elgar. Finlayson, G. 1994. Citizen, State and Social Welfare in Britain 1830-1990. Oxford: Clarendon Press.

Flynn, N. 2012. Public Sector Management, 6th ed. London: Sage.

Giddens, A. 1998. The Third Way: The Renewal of Social Democracy. Cambridge: Polity Press. Harris, B. 2010. "Voluntary Action and the State in Historical Perspective." Voluntary Sector Review 1 (1): 25-40.

HM Treasury. 2002. The Role of the Voluntary and Community Sector in Service Delivery: A Cross Cutting Review. London: HM Treasury.

HM Treasury. 2004. Cross Cutting Review: Follow-up of the Role of the Third Sector in Service Delivery. London: HM Treasury.

HM Treasury. 2005. Exploring the Role of the Third Sector in Public Service Delivery and Reform. London: HM Treasury.

Home Office. 1998. Compact on Relations between Government and the Voluntary and Community Sector in England, Cm. 4100, London: the Stationery Office.

Home Office. 2003. Building Civil Renewal: Government Support for Community Capacity Building and Proposals for Change. London: Home Office.

Kane, D., P. Bass, J. Heywood, V. Jochum, D. James, and G. Lloyd. 2014. The Civil Society Almanac 2014, National Council for Voluntary Organisations, https://www.ncvo.org.uk/ component/redshop/1-publications/P140-uk-civil-society-almanac-2014, accessed 13 August 2015.

Kendall, J. 2003. The Voluntary Sector: Comparative Perspectives in the UK. London: Routledge. Kendall, J. 2009. "The Third Sector and the Policy Process in the UK: Ingredients in a Hyperactive Active Horizontal Policy Environment." In Handbook of Third Sector Policy in Europe: Multi-Level Processes and Organised Civil Society, edited by J. Kendall. Cheltenham: Edward Elgar

Labour Party. 1997. Building the Future Together: Labour's Policies for Partnership between the Government and the Voluntary Sector. London: Labour Party.

Lewis, J. 1995. The Voluntary Sector, the State and Social Work in Britain. Aldershot: Edward Elgar.

Lewis, J. 1999. "Reviewing the Relationship between the Voluntary Sector and the State in Britain in the 1990s." Voluntas: International Journal of Voluntary and Nonprofit Organizations 10 (3): 255-70.

Lewis, J. 2005. "New Labour's Approach to the Voluntary Sector: Independence and the Meaning of Partnership." Social Policy and Society 4 (2): 121-33.

Lindsey, R., and S. Bulloch. 2013. What the public think of the 'Big Society': Mass Observers' views on individual and community capacity for civic engagement, TSRC Working Paper 95 , University of Birmingham.

Macmillan, R. 2013. Making sense of the Big Society: perspectives from the third sector, TSRC Working Paper 90, University of Birmingham.

Macmillan, R., and A. Townsend. 2006. "A 'New Institutional Fix'? the 'Community Turn' and the Changing Role of the Voluntary Sector." In Landscapes of Voluntarism: New Spaces of Health, Welfare and Governance, edited by C. Milligan, and D. Conradson. Bristol: Policy Press. 
Milbourne, L. 2013. Voluntary Sector in Transition: Hard Times or New Opportunities? Bristol:

Policy Press.

National Coalition for Independent Action (NCIA). 2011. The Devil That Is Commissioning. London: NCIA.

Norman, J. 2010. The Big Society: The Anatomy of the New Politics. Buckingham: University of Buckingham Press.

Pollitt, C. 1990. Managerialism and the Public Services. Oxford: Basil Blackwell.

Rochester, C. 2013. Rediscovering Voluntary Action: The Beat of a Different Drum. Basingstoke: Palgrave.

Smerdon M., ed. 2009. The First Principle of Voluntary Action: Essays on the Independence of the Voluntary Sector in Canada, England, Germany, Northern Ireland, Scotland, United States of America and Wales. London: The Baring Foundation.

Teasdale, S. 2012. "What Is in a Name? Making Sense of Social Enterprise Discourses." Public Policy and Administration 27 (2): 99-19.

White Paper. 2011. Open Public Services, Cm 8145, London: the Stationery Office.

Wolfenden Committee. 1978. The Future of Voluntary Organisations. London: Croom Helm. 